\title{
Potato yield on dark gray soils when using microbiological preparation
}

\author{
Irina Pityurina ${ }^{1, *}$ and Dmitry Vinogradov ${ }^{2}$ \\ ${ }^{1}$ Academy of law management of the federal penal service of Russia, 1, Sennaya, Ryazan, 390036 \\ Russian Federation \\ ${ }^{2}$ Ryazan State Agrotechnological University Named after P.A. Kostychev, 1, Kostychev Str., Ryazan, \\ 390044, Russia
}

\begin{abstract}
Increasing the yield and quality of potatoes is one of the most important tasks of potato industry. A promising method of increasing the productivity and quality of potatoes is to use microbiological preparations. Their action is due to the use of the properties of microorganisms that can transform the elements of soil nutrition from forms inaccessible to plants to assimilable ones. Consequently, it can be concluded that the study of potato productivity on the dark gray forest soil using the microbiological preparation Biocomposite-correct is an actual area of research. The results of the conducted research show that the used preparation Biocompositecorrect had a positive effect on the elements of the crop structure and potato yield.The optimal rate of application of the preparation Biocomposite-correct ( $3.0 \mathrm{l} / \mathrm{ha}$ with a working fluid flow rate of $400 \mathrm{l} / \mathrm{ha}$ ), was determined in the course of the experiment. On average, the maximum increase of the mass of potato tubers from one bush was observed in the variant with the use of Biocomposite-correct in the dose $3.0 \mathrm{l} /$ ha +387.1 grams), which is $92.2 \%$ more compared to the control, where the maximum yield was 24.2 tons/ha.
\end{abstract}

\section{Introduction}

One of the most important crops is potato. It stands on the same stage as crops such as wheat, corn, rice in the world production of crop production [1].

Increasing the yield and quality of potatoes in our time is one of the most important tasks in the potato industry. In modern conditions, it is important to observe agricultural techniques for cultivating potatoes and the use of biological preparations that can limit the spread of infectious diseases in the field and ensure the maximum quality of potatoes $[3,5,6]$. One such technique for improving potato productivity and quality is the use of microbiological preparations. Their effect is due to the use of the properties of microorganisms capable of converting soil nutritional elements from forms inaccessible to plants to digestible ones. At the same time, high concentrations of such drugs are not required and it is possible to use them together with pesticides familiar for use in crop production. It is microbiological preparations that can affect the resistance to pathogens of

\footnotetext{
*Corresponding author : piturina@yandex.ru
} 
various diseases, the physiological and biochemical processes that occur in plants, the functioning of their immune system, and as a result of all these processes, the productivity and quality of potato varieties [8,11,13].

In this regard, it can be concluded that the study of potato productivity on dark gray forest soils using the microbiological preparation Biocomposite correction is an urgent area of research [2-4,16,17].

\section{Materials and methods}

The experiments were carried out in the conditions of the Ryazan region, on dark gray forest heavy coal soil, in 2015-2020.

Agrochemical indicators of the soil: $\mathrm{pH}$ 5.6-5.8, the reaction of the soil solution is slightly acidic; humus $3.2-3.9 \%$, is medium humus, medium fertile; mobile forms of phosphorus 153-160 mg/kg (low), potassium -350-442 mg/kg (above average).

The object of research was the variety of Gala potatoes, which is medium-ripe for table purposes.

The experiment was staged by treating potatoes in the butonization phase with a microbiological preparation Biocomposite correction in the following ways: 1) control (without using a microbiological preparation); 2) Biocomposite correction with flow rate of 1 l/ha; 3) Biocomposite correction, 2 l/ha; 4) Biocomposite correction, 3 l/ha; and 5) Biocomposite correction, 4 l/ha. Operating fluid flow rate is 400 l/ha [12,14,15].

Zavorov potato growing technology was used as a base. Agrotechnical techniques during the experiments were carried out in the optimal time frame.

Winter ears were chosen as the antecedent. The experiment was conducted with quadruple repetition. Potato tubers were planted in the first part of May. A fraction of tubers 70-85 g was selected.

Landing was carried out according to the scheme $70 \times 30$ with the norm $3.3 \mathrm{t} / \mathrm{ha}$. The total area of the plot was $75 \mathrm{~m}^{2}$, counting $60 \mathrm{~m}^{2}$.

During the vegetation of experimental plantings, the following treatments were used: 1 ) Zenkor herbicide was used to control weeds until seedlings appeared in a dosage of 1.4 $\mathrm{kg} / \mathrm{ha}$; 2) in global lesion of planting by larvae of Colorado beetle, treatment with double spraying with insecticide Karate Zeon at dosage 0.1 l/ha.

A suspension with culture fluid of a consortium of highly effective strains of various types of bacteria, some of which have not previously been used in microbiological preparations for agricultural purposes. Biocomposite correction includes composition of living bacteria culture and results of their metabolism.

Studies were carried out according to standard, generally accepted methods in accordance with regulatory documents. The implementation and processing of the results of the experiment was carried out by the method of dispersion analysis of Dospekhov B.A. (1985), and the "Methods of Research on Potato Culture" developed by the All-Russian Potato Research Institute (NIIKH, 1967) [7,9,10].

\section{Results}

The results of the studies show that the Biocomposite correction used had a positive effect on the elements of the crop structure and potato yield (Table 1). 
Table 1. Elements of potato crop structure at different norms of biopreparation Biocomposite correction in the butonisation phase, average for 2015-2020.

\begin{tabular}{|c|c|c|c|}
\hline Variants & $\begin{array}{c}\text { Mass of tubers with 1 } \\
\text { potato bush, gram }\end{array}$ & $\begin{array}{c}\text { Number of tubers with } \\
\text { 1 bush, pieces }\end{array}$ & $\begin{array}{c}\text { Average weight 1 } \\
\text { tuber, gram }\end{array}$ \\
\hline Control & 419.8 & 7.2 & 58.3 \\
\hline $\begin{array}{c}\text { Biocomposite } \\
\text { correction,1.0 l/ha }\end{array}$ & 567.8 & 8.9 & 63.8 \\
\hline $\begin{array}{c}\text { Biocomposite } \\
\text { correction, 2.0 l/ha }\end{array}$ & 595.0 & 8.7 & 68.4 \\
\hline $\begin{array}{c}\text { Biocomposite } \\
\text { correction, 3.0 l/ha }\end{array}$ & 806.9 & 11.1 & 72.7 \\
\hline $\begin{array}{c}\text { Biocomposite } \\
\text { correction, 4.0 l/ha }\end{array}$ & 767.2 & 9.2 & 83.4 \\
\hline
\end{tabular}

On average, the maximum increase in the mass of tubers from one bush of potato is marked on the Biocomposite correction version, 3 l/ha (+ 387.1 grams), by $92.2 \%$, compared with the control. A high number of tubers from one plant was observed in the microbiological fertilizer treatment version with a dose of $3 \mathrm{l} / \mathrm{ha}$ (11.1 pieces). The largest indicator for the average weight of one tuber was noted on the Biocomposite correction version, 4 l/ha (83.4 grams).

A tendency to increase the tuber yield with an increase in various doses of the drug was revealed.

Table 2.Yield of Gala variety at different norms of biopreparation in the butonisation phase, tons/ha

\begin{tabular}{|c|c|c|c|c|c|c|c|}
\hline Variants & $\begin{array}{c}2015 \\
\text { year }\end{array}$ & $\begin{array}{c}2016 \\
\text { year }\end{array}$ & $\begin{array}{c}2017 \\
\text { year }\end{array}$ & $\begin{array}{c}2018 \\
\text { year }\end{array}$ & $\begin{array}{c}2019 \\
\text { year }\end{array}$ & $\begin{array}{c}2020 \\
\text { year }\end{array}$ & Average \\
\hline control & 20.6 & 21.3 & 22.3 & 12.6 & 25.2 & 27.9 & 21.6 \\
\hline $\begin{array}{c}\text { Biocomposite correction , } \\
\text { 1.0 l/ha }\end{array}$ & 21.4 & 21.3 & 22.5 & 13.7 & 27.6 & 28.4 & 22.4 \\
\hline $\begin{array}{c}\text { Biocomposite correction , } \\
\text { 2.0 l/ha }\end{array}$ & 21.3 & 21.6 & 23.1 & 14.3 & 27.9 & 31.0 & 23.2 \\
\hline $\begin{array}{c}\text { Biocomposite correction , } \\
\text { 3.0 l/ha }\end{array}$ & 21.9 & 22.0 & 24.9 & 16.0 & 29.0 & 31.5 & 24.2 \\
\hline $\begin{array}{c}\text { Biocomposite correction , } \\
4.0 \text { l/ha }\end{array}$ & 21.7 & 21.8 & 24.4 & 15.8 & 28.0 & 31.7 & 23.9 \\
\hline NSR $_{05}$ ton/ha & 0.32 & 4.29 & 3.80 & 3.89 & 1.74 & 2.02 & \\
\hline
\end{tabular}

On average, over the years 2015-2020, there was a positive tendency to increase the yield of potato plantings by treatment in the butonization phase with a consumption rate of Biocomposite correction (Table 2), 3 l/ha (24.2 tons/ha). The maximum increases in tubers 
were recorded in 2017, 2019, and 2020. The highest yield was obtained in 2020 on plots with Biocomposite correction treatment, 4 l/ha (31.7 tons/ha).

Analyzing the economic efficiency of options in potato production technology, the control option in the experiment was economically unprofitable. The maximum in experiment cost of 1 ton of products (\$111.8) under control, without microbiological fertilizer treatment, and low profitability $(72.0 \%)$ are due to not high tuber yields. On average, the maximum profitability was achieved on the Biocomposite correction version, 3 $1 /$ ha $(80.2 \%)$, which is $+8.2 \%$ higher than the control version.

The carried out studies make it possible to conclude that the microbiological preparation Biocomposite-correction also had an influence on thebiochemic composition of Gala potato tubers (Figure 1).
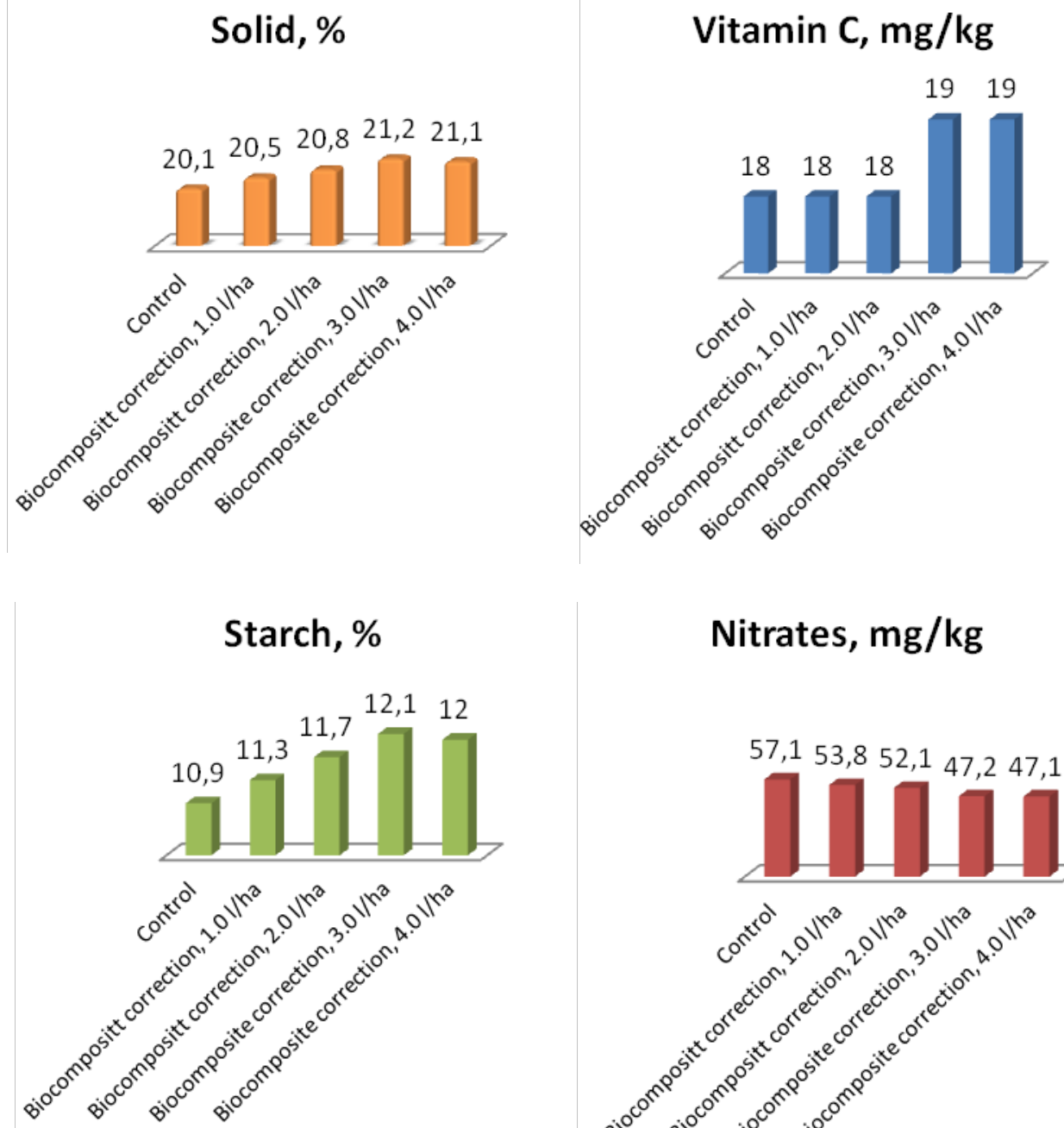

\section{Nitrates, $\mathrm{mg} / \mathrm{kg}$}

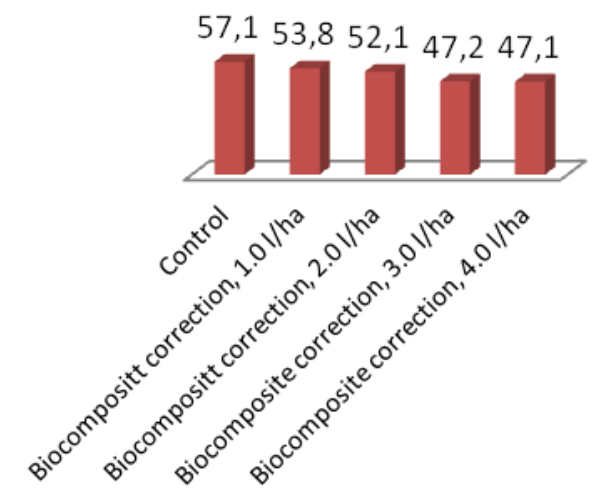

Fig. 1. Effect of microbiological treatment Biocomposite correction in different norms of application on biochemical composition of potato tubers of Gala variety

As can be seen from Figure 1, the use of the microbiological preparation Biocomposite correction as a whole positively affected the biochemical composition of Gala potato 
tubers. Application rates of $3.0 \mathrm{l} / \mathrm{ha}$ and $4.0 \mathrm{l} / \mathrm{ha}$ on average over the years of research showed the best and practically the same results for the investigated indicators (content of dry matter, vitamin C, nitrates, starch). Compared to the control, there was an increase in dry matter content by an average of $4.9 \%$, vitamin C by $5.5 \%$, starch by $10.1 \%$. The nitrate content on average decreased by $17.5 \%$ compared to the control.

The analysis of the obtained data suggests that the use of Biocomposite-corrects positively affects the biochemical composition of Gala potato tubers in all application rates, but the best and practically the same values were achieved at a rate of $3.0 \mathrm{l} / \mathrm{ha}$ and $4.0 \mathrm{l} / \mathrm{ha}$.

\section{Conclusion}

Thus, in the experiment, the optimal rate of application of the preparation Biocomposite correction, 3.0 l/ha with a working fluid consumption of $400 \mathrm{l} / \mathrm{ha}$ was determined. On average, the maximum increase in tuber weight from one potato bush was noted in the version Biocomposite correction, $3.0 \mathrm{l} / \mathrm{ha}$ ( +387.1 grams), by $92.2 \%$, compared with the control, where the maximum yield was 24.2 tons/ha. The highest yield was obtained in 2020 on plots with Biocomposite correction treatment, 4 l/ha (31.7 tons/ha).

As can be seen from Figure 1, the use of the microbiological preparation Biocomposite correction as a whole positively affected the biochemical composition of Gala potato tubers. Application rates of $3.0 \mathrm{l} / \mathrm{ha}$ and $4.0 \mathrm{l} / \mathrm{ha}$ on average over the years of research showed the best and practically the same results for the investigated indicators (content of dry matter, vitamin C, nitrates, starch). Compared to the control, there was an increase in dry matter content by an average of $4.9 \%$, vitamin C by $5.5 \%$, starch by $10.1 \%$. The nitrate content on average decreased by $17.5 \%$ compared to the control

\section{References}

1. D.V. Vinogradov, K.V Naumtseva,., E.I Lupova. Use of biological fertilizers in white mustard crops in the non-Chernozem zone of Russia / IOP Conference Series: Earth and Environmental Science, 341(1), 012204 (2009)

2. T.V. Khabarova, D.V. Vinogradov, B.I. Kochurov, V.I. Levin, N.V. Byshov Agroecological efficiency of sewage sludge and vermicompost in agrocenoses of cultivated oat / South of Russia: Ecology, Development, 13(2), pages. 132-143 (2018)

3. O.N. Terekhina. Innovative Biologics for Ecological Agriculture - Life Technology/Healthy Environment - The Basis of Regional Security: In Sb. materials of the first international environmental forum in Ryazan. FSBOU VO RGATU. Volume 2. - Pages. 272-277 (2017)

4. O.V. Meleshina, A.A. Meleshin Creation of the potato with raised antioxidant activity - the new direction in selection of modern grades/ Modern Science Success, Vol. 1. Pp. 47-52 (2017)

5. S.V. Gevora, V.I. Starovoitov, O.A. Starovoitova, A.A. Manokhina. The influence of humic substances on productivity of potato/ Modern Science Success, Vol. 2. Issue 9. Pp. 61-67 (2017)

6. A.R. Devi, R. Kotoky, P. Pandey, G.D. Sharma. Applica-tion of Bacillus spp. for Sustainable Cultivation of Potato (Solanum tuberosum L.) and the Benefits 2016/ Bacilli and Agrobiotechnology. Ed-itors: Islam, M.T., Rahman, M.M., Pandey, P., Jha, C.K., Aeron, Cham: Springer In-ternational Publishing AG. - P. 185-212 (2016) 
7. V. Vasileva. Aboveground to root biomass ratios in pea and vetch after treatment with organic fertilizer, Global Journal of En-vironmental Science and Management (GJESM). 1 (2): 71-74 (2015)

8. G. Barnes. The use of plant growth regulator, Chem. Ind., pp.799-805 (1984)

9. R.G. Rowberry \& G.H.Collin. The effects of humic acid de-rivatives on the yield and quality of Kennebec and Sebago potatoes, American Potato Journal, vol. 54, no. 12, pp. 607-609 (1977)

10. H.Y. Suh, K.S. Yoo \& S.G. Suh. Tuber growth and quality of potato (Solanum tuberosum L.) as affected by foliar or soil applica-tion of fulvic and humic acids, Horticulture, Environment, and Bi-otechnology, vol. 55, no. 3, pp. 183-189 (2014)

11. A.D. Andrianov, D.A. Andrianov. Fertilizers and phyto-regulators increase the immunity and productivity of early potatoes. Potatoes and vegetables, no4, pp. 11-12 (2006)

12. Eh.V. Zasorina, Yu. M. Priymenko, V.V. Vlasov. Inno-vative techniques of potato cultivation in the conditions of the Cen-tral Black Soil Region. Herald of Kursk Agricultural Academy, no 5, pp. 47-49 (2015)

13. O. Schmeil, J. Fitschen. Flora von Deutschland und angrenzender Lander, Bearb. Seybold uberarbeitete Auflage, 864 S., 91 (2000)

14. E.I. Lupova, E.A. Vysotskaya. Improvement of elements of oil flax cultivation technology on gray forest soil. IOP Conf. Series: Earth and Environmental Science 422, 012081(2020)

15. N V Byshov, M B Latyshenok, V A Makarov, N M Latyshenok, A V Ivashkin Prospects and method of seed grain storage in a container with gas-regulating medium. IOP Conf. Series: Earth and Environmental Science 624, 012118(2021)

16. N.V. Byshov, A.A. Simdyankin, I.A. Uspensky, R.V. Pukov Accounting for the time of ultrasonic fuel processing in the surface tension coefficien. ARPN Journal of Engineering and Applied Sciences.. T. 14 № 21. s. 3753-3756. (2019)

17. D.V. Vinogradov, O.N. Terekhina, N.V. Byshov, M.M. Kryuchkov, N.I. Morozova, O.A. Zakharova Features of applying biological preparations in the technology of potato growing on gray forest soils. International Journal of Engineering and Technology. Vol 7, No 4.36. P. 242-246 (2018) 